\title{
The Ownership Structure and the Performance of the Polish Stock Listed Companies
}

\author{
Dr Anna Blajer-Gołębiewska \\ Department of Microeconomics \\ Faculty of Economics \\ University of Gdansk \\ a.blajer@ug.edu.pl
}

\begin{abstract}
The ownership of a company can be classified into inside ownership and outside ownership. According to Alignment Theory, there is a positive relation between the inside ownership and a company performance. However, there have been some researches that indicate the opposite relation. This is explained by the Enhancement Theory.

The aim of the research is to indentify of the relationship between shareholders structure and the company's performance in case of the Polish stock listed companies. The research is based on data for companies listed on the main market of the Warsaw Stock Exchange.

The main thesis is that there is no evident the relation between shareholders structure and company's performance as the optimal ownership structure depends on a wide array of factors such as branch, market concentration, costs structure etc. As a result, it is also hard to indicate the optimal percentage of inside ownership, which is needed for profit optimization. The first stage of task realization was the analysis of various theories on relationship between ownership structure and the company's performance. Then ownership characteristics and financial characteristics were determined and analysed. The last stage was the analysis of correlation between ownership structure and the Polish stock listed companies' performance.
\end{abstract}

Keywords: Capital and Ownership Structure, Firm Performance, Financial Market, Corporate Finance and Governance

Submitted: May, 2010 $1^{\text {st }}$ revision: June, 2010 Accepted: July, 2010

JEL classification: L25, L33, P2

\section{Introduction}

Within the literature there is a wide range of researches conducted on the relation between the ownership structure and company performance. However, they lead to different conclusions. The aim of this research is to identify the correlation between shareholders structure and the company's performance for the companies listed on the Warsaw Stock Exchange. The research was conducted for the Polish companies listed on the main market in years 2008 and 2009.

The first stage of task realization was the analysis of various theories on relation between ownership structure and the company's performance. Then ownership characteristics 
and financial characteristics were determined and analysed. The last stage encompassed the analysis of correlation between ownership structure and the Polish stock listed companies' performance.

The main thesis is that, according to the Trade-off Theory, there is no evident relationship between shareholders structure and company's performance as the optimal ownership structure depends on wide range of factors such as branch, market concentration, costs structure and other. To conduct a research on the correlation between shareholders structure and the company's performance at first various theories should be analyzed.

\section{Theories of relationship between shareholders structure and the company's performance}

The relationship between inside and outside shareholders is rooted in the Agency Theory and the Theory of the Firm. When applying the Agency Theory to this problem, the principals are the outside shareholders and the agents are the managers responsible for running the firm. The agency problem is that interests of the managers are not aligned with the interests of the outside shareholders. Their motives can differ, so each of these two groups can even create information asymmetry to pursue their particular interest. The lower the level of information asymmetry, the better the cooperation within those two groups and their performance.

According to the Agency Theory, the higher level of inside shareholders has an influence on the decrease of information asymmetry, which should lead to higher company performance. Insiders are interested in higher profits. These individuals belong to the only group of shareholders who can have direct impact on the way the company is managed. Furthermore, insiders have access to additional or private information that other shareholders do not have, so if insiders buy or sell their shares, it can work as a signal of better or worse condition of the company.

To align the incentives of the managers with those of the shareholders, companies use various compensation-based incentive arrangements. The level of information asymmetry can be also lower when the managers themselves become shareholders and take an ownership interest in the firm. In other words, the performance of the firm will increase as the level of inside ownership increases. Moreover, researches indicate that inside ownership increases performance at decreasing rates. Any increase in the number of shares held, according to the theory of decreasing marginal utility, will produce a smaller increase in employees' satisfaction from their possession, and hence to a lesser extent will motivate employees to increase its productivity. This relation is known as the Alignment Theory (Jensen and Meckling, 1976). According to the Alignment Theory and the Agency Theory, the best performing firms should have very high levels of inside ownership and this level should be appropriate proxy for the level of asymmetric information.

One of researches, confirming the Alignment Theory and the Agency Theory, was conducted by $\varnothing$. Bøhren i B. A. Ødegaard (2003). The authors took into consideration the companies listed on The Oslo Stock Exchange. According to the research, for the companies, with a high number of inside shareholders, the level Q-Tobin index (as the quotient of the market value of assets and the replacement value of assets market value of the assets) is higher. With reference to Stein (1989), the inside ownership has a positive impact on company performance especially in the case of family-owned companies. As family members are deeply involved in the company management, they have firm-specific knowledge and longer investment horizons. As a result, they make better investment decisions.

Demsetz (1983) argues that ownership structure is an endogenous outcome of decisions that reflect subsequent trading on the market for shares. As the ownership structure 
ought to be influenced by the aim of profit-maximizing interest of shareholders, there ought to be relation between variation in ownership structure and company performance.

However, not all researches confirm the Alignment Theory. As evidences suggest that the opposite relation may actually hold true, the validity of the alignment theory has been questioned by researchers.

What explains the phenomenon of opposing effects of inside ownership on firm's performance, (lower inside ownership - higher company performance) is the Entrenchment Theory. It maintains that if the manager gets shares in the firm and gains a greater control he has no incentives to remove from his position (Stulz 1988). The entrenched manager may pursue only his own interests that do not have to be directly beneficial to the other shareholders, such as excessive salaries or appointing family members to managerial positions (Shleifer and Vishny 1986). As a result, inside ownership decreases performance at increasing rates (picture 1).
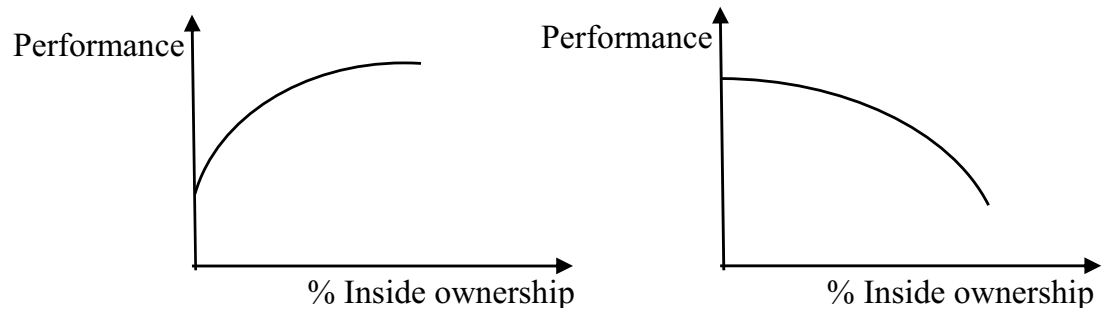

Picture 1. Alignment Theory vs. Entrenchment Theory

Source: own compilation based on: Insider Ownership and REIT Performance - Is More Always Better? (2001).

Higher inside ownership (55\% or more) is sometimes considered as the signal of a higher risk. It is because the insiders may be major investors waiting for the opportune time to sell their shares. And when large shareholders put millions of shares onto the market, the price of shares will slump. Moreover, high insider ownership may reflect companies owned by the founding family who may not see an advantage of higher share prices.

The results of the conducted research often lead to different conclusions. However, these contradictions are only seeming. The Trade-off Theory links the Alignment Theory and the Entrenchment Theory.

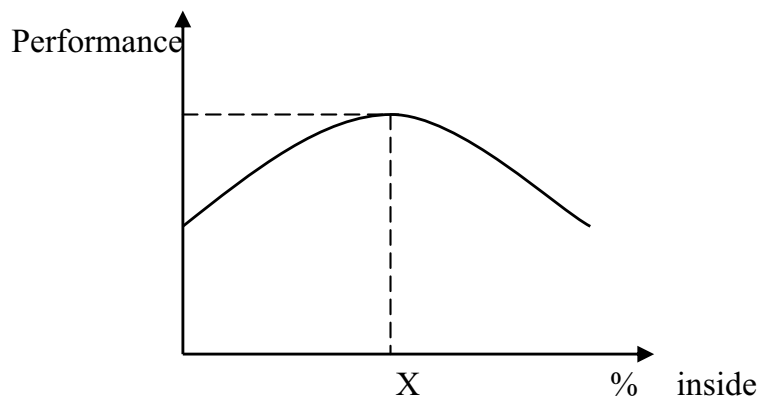

Picture 2. Trade-off Theory

Source: own compilation, on the basis of Insider Ownership ..., op. cit. 
According to Trade-off Theory, at a very low level of inside ownership, its growth influences the company's performance, since the Alignment Theory dominates (picture 2). For a high level of inside shareholders, there is a negative relation between the inside shareholders and company performance (domination of the Entrenchment Theory). However, the Trade-off Theory does not give the answer to the problem of the optimal percentage of inside ownership determination (x). The optimal ownership structure depends on a specific company. Therefore, it is hard to determine the relation between the structure of ownership and company performance in certain cases without further research into these issues.

The next effect that can be examined is the relation between the ownership of large shareholders or even between the number of large shareholders and a company performance. The relation between ownership structure and company performance has been the subject of the researches mostly since Berle's and Means's "The Modern Corporation and Private Property" (1932). According to their research there should be an inverse correlation between the diffuseness of shareholdings and company performance.

Shleifer's and Vishny's (1986) research argues that controlling blockholders are more capable of controlling managers, even if the blockholders are not directly involved in management. That can lead to profit-maximizing decisions in the interest of shareholders.

However, this problem is also controversial. O'Sullivan and Wong (1998) examined the relationship between board composition, ownership structure and takeovers in the UK. The result of the research shows that the ownership of large shareholders is positively associated with the takeover likelihood, which is coherent with the mentioned theory that higher inside ownership (55\% or more) is the signal of higher risk.

\section{Ownership structure and performance of the Polish stock listed companies}

The research on ownership structure and performance of the Polish Stock listed companies was conducted on the basis of The Warsaw Stock Exchange data and data available on websites of each company. 289 companies were analysed, each of them listed on The Warsaw Stock Exchange in the year 2008 and 2009. In order to achieve homogeneous dataset, only Polish companies quoted on the main market were taken into consideration.

\section{Ownership characteristics}

In order to determine inside ownership, the percentage of stock owned by employees, directors, officers or other key executives in the company was calculated. Moreover, in some cases, also the shares of primary owners should be taken into consideration, as they have an important impact on the way the company is managed and they still possess an informal access to private information about the company.

The indicators for shares of inside and outside shareholders were determined on the basis of the contents of companies' websites and the archival data on financial portals such as bankier.pl and money.pl. Archival data were necessary to indicate the connections between each shareholder and a company, which allowed to construct the outside shareholders indicator. It was assumed that shares of each person who had personal connections with a member of management board, were calculated into inside ownership indicator. Following the same rule, if there had been any company, subsidiary to the analysed one, its shares were also calculated into inside ownership indicator.

The set of ownership structure indicators contains:

- number of large shareholders,

- percentage of shares owned by large shareholders,

- percentage of voting rights of the largest shareholders, 
- percentage of voting rights of the largest shareholder,

- percentage of voting rights of the largest outside shareholders,

- percentage of shares owned by the members of management board,

- free float,

- percentage of shares owned by outside shareholders.

The research was conducted not only for the whole group of stock listed companies, but also by sector. According to the Warsaw Stock Exchange, the companies were divided into 21 sectors (Table 1).

Table 1. Industry sectors according to the Warsaw Stock Exchange

\begin{tabular}{|l|l|l|l|l|l|}
\hline No. & $\begin{array}{l}\text { abbreviation } \\
(\mathrm{PL})\end{array}$ & SECTOR & No. & $\begin{array}{l}\text { abbreviation } \\
(\mathrm{PL})\end{array}$ & SECTOR \\
\hline 1 & ban & Banking & 11 & hir & $\begin{array}{l}\text { Hotels \& } \\
\text { Restaurants }\end{array}$ \\
\hline 2 & bud & Construction & 12 & inf & IT \\
\hline 3 & che & Chemicals & 13 & lek & Light Industry \\
\hline 4 & dew & Developers & 14 & mbu & Building materials \\
\hline 5 & drz & Wood \& Paper & 15 & med & Media \\
\hline 6 & ele & Electroengineering & 16 & met & Metals \\
\hline 7 & ene & Energetics & 17 & pal & Oil \& Gas \\
\hline 8 & fin & Finance - other & 18 & pin & Other Industries \\
\hline 9 & had & Retail & 19 & spo & Food \\
\hline 10 & hah & Wholesale & 20 & tel & Telecom \\
\hline & & & 21 & uin & Services - other \\
\hline
\end{tabular}

Source: own compilation on the basis of Warsaw Stock Exchange's website (www.gpw.pl)

The analysis of ownership structure by branch (table 2) shows high concentration of ownership in case of Hotels \& Restaurants sector $(78.69 \%$ of shares was owned by large shareholders) and Banking sector ( $77.30 \%$ of shares was owned by large shareholders). Whereas the highest level of free float was noticed in the case of Light Industry sector. What is interesting is the fact that in banking sector, the percentage of shares owned by the management board was close to zero. In the following sectors: Banking, Financial - others, Developers and Hotels \& Restaurants, percentage of voting rights of the largest share-holder is $50 \%$ or more.

As a result, due to such indicators as percentage of voting rights or number of shares owned by large shareholders, percentage of voting rights of the largest shareholder and free float, the sectors of visibly high concentration of ownership can be determined. These are: Banking, Finance - other, Hotels \& Restaurants, Chemicals, Developers and Services-other. The lowest concentration of ownership was found in Light Industry.

The highest inside ownership can be found in Banking sector, as only $30.98 \%$ of shares was owned by outside shareholders and only $8.28 \%$ of voting rights was in possession of the largest outside shareholders. There is no other so sector of such high a inside ownership. However, in Hotels \& Restaurants sector, only $44.20 \%$ shares were owned by outside shareholders. For the other companies, analysed the percentage of shares owned by outside shareholders is $50 \%$ or more. 
Table 2. Average financial indicators for each branch on the Warsaw Stock Exchange

\begin{tabular}{|c|c|c|c|c|c|c|c|c|}
\hline $\begin{array}{l}\text { sec- } \\
\text { tor }\end{array}$ & $\begin{array}{c}\text { number } \\
\text { of large } \\
\text { share- } \\
\text { holders }\end{array}$ & $\begin{array}{l}\text { percentage } \\
\text { of shares } \\
\text { owned by } \\
\text { large share- } \\
\text { holders }\end{array}$ & $\begin{array}{l}\text { percentage } \\
\text { of voting } \\
\text { rights } \\
\text { of the } \\
\text { largest } \\
\text { share- } \\
\text { holders } \\
\end{array}$ & $\begin{array}{l}\text { free } \\
\text { float }\end{array}$ & $\begin{array}{l}\text { percentage } \\
\text { of voting } \\
\text { rights of } \\
\text { the largest } \\
\text { share- } \\
\text { holder }\end{array}$ & $\begin{array}{l}\text { percentage } \\
\text { of voting } \\
\text { rights of } \\
\text { the largest } \\
\text { outside } \\
\text { share- } \\
\text { holders }\end{array}$ & $\begin{array}{c}\text { percentage } \\
\text { of shares } \\
\text { owned by } \\
\text { the } \\
\text { members } \\
\text { of manage- } \\
\text { ment board }\end{array}$ & $\begin{array}{l}\text { percentage } \\
\text { of shares } \\
\text { owned by } \\
\text { the outside } \\
\text { share- } \\
\text { holders }\end{array}$ \\
\hline ban & 1.79 & $77.30 \%$ & $76.95 \%$ & $22.70 \%$ & $72.33 \%$ & $8.28 \%$ & $0.00 \%$ & $30.98 \%$ \\
\hline bud & 4.04 & $60.11 \%$ & $61.86 \%$ & $39.89 \%$ & $36.28 \%$ & $36.33 \%$ & $7.50 \%$ & $76.22 \%$ \\
\hline che & 3.37 & $67.38 \%$ & $68.09 \%$ & $32.62 \%$ & $45.11 \%$ & $52.52 \%$ & $6.18 \%$ & $85.15 \%$ \\
\hline dew & 2.78 & $65.77 \%$ & $69.16 \%$ & $34.23 \%$ & $54.04 \%$ & $26.93 \%$ & $6.57 \%$ & $61.16 \%$ \\
\hline drz & 4.00 & $59.83 \%$ & $59.83 \%$ & $40.17 \%$ & $40.03 \%$ & $32.17 \%$ & $2.62 \%$ & $72.34 \%$ \\
\hline ele & 3.25 & $66.77 \%$ & $69.39 \%$ & $33.23 \%$ & $46.44 \%$ & $27.88 \%$ & $17.04 \%$ & $61.12 \%$ \\
\hline ene & 5.00 & $58.53 \%$ & $58.53 \%$ & $41.47 \%$ & $16.10 \%$ & $58.53 \%$ & $0.00 \%$ & $100.00 \%$ \\
\hline fin & 3.00 & $67.33 \%$ & $74.99 \%$ & $32.67 \%$ & $52.33 \%$ & $23.31 \%$ & $14.93 \%$ & $55.98 \%$ \\
\hline had & 3.50 & $63.97 \%$ & $68.16 \%$ & $36.03 \%$ & $40.06 \%$ & $20.19 \%$ & $26.73 \%$ & $56.23 \%$ \\
\hline hah & 3.29 & $63.41 \%$ & $69.28 \%$ & $36.59 \%$ & $40.00 \%$ & $23.07 \%$ & $25.90 \%$ & $59.66 \%$ \\
\hline hir & 3.00 & $78.69 \%$ & $81.37 \%$ & $21.31 \%$ & $52.02 \%$ & $22.89 \%$ & $33.90 \%$ & $44.20 \%$ \\
\hline inf & 3.65 & $55.54 \%$ & $59.13 \%$ & $44.14 \%$ & $29.44 \%$ & $24.23 \%$ & $24.06 \%$ & $68.37 \%$ \\
\hline lek & 2.75 & $45.73 \%$ & $45.82 \%$ & $54.27 \%$ & $29.00 \%$ & $31.86 \%$ & $11.09 \%$ & $86.13 \%$ \\
\hline $\mathrm{mbu}$ & 2.71 & $58.87 \%$ & $61.08 \%$ & $41.13 \%$ & $42.92 \%$ & $27.72 \%$ & $20.21 \%$ & $68.85 \%$ \\
\hline med & 3.23 & $60.15 \%$ & $63.57 \%$ & $39.77 \%$ & $38.54 \%$ & $34.49 \%$ & $14.17 \%$ & $74.26 \%$ \\
\hline met & 2.63 & $65.86 \%$ & $66.72 \%$ & $34.14 \%$ & $49.66 \%$ & $49.55 \%$ & $5.17 \%$ & $83.69 \%$ \\
\hline pal & 2.80 & $61.34 \%$ & $61.34 \%$ & $37.08 \%$ & $44.63 \%$ & $49.57 \%$ & $0.00 \%$ & $86.66 \%$ \\
\hline pin & 3.00 & $59.05 \%$ & $61.57 \%$ & $40.95 \%$ & $36.73 \%$ & $17.74 \%$ & $31.74 \%$ & $58.70 \%$ \\
\hline spo & 2.41 & $58.54 \%$ & $61.58 \%$ & $41.46 \%$ & $43.98 \%$ & $18.28 \%$ & $15.04 \%$ & $59.74 \%$ \\
\hline tel & 3.50 & $58.60 \%$ & $60.05 \%$ & $41.40 \%$ & $39.69 \%$ & $28.18 \%$ & $0.77 \%$ & $69.58 \%$ \\
\hline uin & 3.20 & $69.80 \%$ & $71.38 \%$ & $30.20 \%$ & $48.76 \%$ & $26.10 \%$ & $23.17 \%$ & $56.29 \%$ \\
\hline
\end{tabular}

Source: own compilation.

The percentage of shares owned by the members of management board was the highest for Hotels \& Restaurants sector and sector of Other Industries. There were almost no shares owned by members of management board in case of Banking sector, Energetics sector and Oil \& Gas sector.

\section{Financial characteristics}

The financial data were based on The Warsaw Stock Exchange data and each company's website. The following data were taken into consideration:

- number of outstanding shares,

- capitalization,

- book value (BV),

- dividend yield in percent,

- net profit on continuous activities,

- equity,

- $\mathrm{P} / \mathrm{BV}$ - price to book value ratio, where the book value is calculated as the company's total tangible assets minus its total liabilities. In other words, it denotes the portion of the 
company held by the shareholders. While interpreting this indicator one should remember that the value of $\mathrm{P} / \mathrm{BV}$ varies by industry. Capital intensive industries will usually trade at the lower $\mathrm{P} / \mathrm{B}$ ratios. However, generally, a higher $\mathrm{P} / \mathrm{B}$ ratio implies that investors expect the management to create more value from a given set of assets $\mathrm{cp}$. But the ratio does not directly provide any information on the ability of the company to generate profits for shareholders;

- $\mathrm{P} / \mathrm{E}$ - price to earnings ratio, price multiple; a high value of $\mathrm{P} / \mathrm{E}$ suggests that investors are expecting higher earnings growth in the future. As in the case of $\mathrm{P} / \mathrm{BV}$, it varies by industry. As a result, it is more useful to compare the $\mathrm{P} / \mathrm{E}$ ratios of the company to other companies in the same industry.

Average financial indicators for each branch are presented in table 3. Most of the companies analysed did not exceed the level of PLN $500 \mathrm{~m}$ in the net profit on continuous activities in 2008 .

Table 3. Average financial indicators for each branch on the Warsaw Stock Exchange [PLN]

\begin{tabular}{|c|c|c|c|c|c|c|}
\hline sector & $\begin{array}{c}\text { number of } \\
\text { outstanding } \\
\text { shares }\end{array}$ & $\begin{array}{c}\text { capitalization } \\
{[\mathrm{m}]}\end{array}$ & $\begin{array}{c}\text { book value } \\
{[\mathrm{m}]}\end{array}$ & $\begin{array}{c}\text { dividend yield } \\
{[\%]}\end{array}$ & $\begin{array}{c}\text { net profit } \\
\text { on continuous } \\
\text { activities }[\mathrm{K}]\end{array}$ & equity $[\mathrm{K}]$ \\
\hline ban & 261538128 & 7821.71 & 4316.77 & 2.68 & 787749.79 & 4472596.79 \\
\hline bud & 52449485 & 464.17 & 250.00 & 1.80 & 34592.91 & 228155.43 \\
\hline che & 263330470 & 366.16 & 573.06 & 2.81 & 16389.11 & 512928.53 \\
\hline dew & 153020126 & 320.67 & 637.45 & 1.46 & 52714.11 & 659407.44 \\
\hline drz & 58373076 & 389.00 & 355.32 & 6.03 & -17564.43 & 333573.71 \\
\hline ele & 42256033 & 151.54 & 221.31 & 2.41 & 5965.88 & 213681.33 \\
\hline ene & 16829084 & 224.80 & 476.89 & 1.95 & 54441.50 & 495874.50 \\
\hline fin & 40833746 & 103.05 & 132.11 & 0.60 & -19232.75 & 140273.75 \\
\hline had & 181845634 & 399.39 & 184.66 & 0.91 & 23385.78 & 194507.78 \\
\hline hah & 14702177 & 115.17 & 151.46 & 2.90 & 7620.82 & 144285.22 \\
\hline hir & 19584644 & 368.00 & 406.44 & 0.24 & -6613.00 & 388910.80 \\
\hline inf & 55679596 & 195.03 & 183.31 & 1.83 & 21658.87 & 209674.16 \\
\hline lek & 168586719 & 65.00 & 95.80 & 0.00 & -26476.13 & 81701.13 \\
\hline $\mathrm{mbu}$ & 35909256 & 236.00 & 226.17 & 1.69 & -1612.29 & 202514.86 \\
\hline med & 81398060 & 821.15 & 295.82 & 1.33 & 58310.54 & 304429.15 \\
\hline met & 43330022 & 639.06 & 919.22 & 3.54 & 194708.06 & 955399.81 \\
\hline pal & $\begin{array}{r}1293565 \\
957\end{array}$ & 6785.00 & 9810.03 & 2.32 & -298427.80 & 8873866.80 \\
\hline pin & 26859646 & 183.00 & 115.79 & 0.00 & 594.75 & 109483.25 \\
\hline spo & 45326295 & 202.65 & 222.45 & 1.08 & 3522.06 & 216110.24 \\
\hline tel & 323309923 & 4740.67 & 3361.18 & 1.83 & 414147.67 & 3308584.00 \\
\hline uin & 43162603 & 121.90 & 115.09 & 2.05 & 7351.60 & 113216.40 \\
\hline
\end{tabular}

Source: own compilation. 
Only 9 companies listed on the stock exchange, mainly in Banking sector, achieved higher net profits on continuous activities: BRE, BZWBK, GETIN, HANDLOWY, PEKAO and PKOBP. There were also 3 other companies with such a high net profit: TP SA (Media sector), PGNIG (Oil \& Gas sector) and KGHM (Metals sector).

In only 36 companies ( $12.5 \%$ of companies) the capitalization was higher than PLN $1000 \mathrm{mln}$. In this case, the domination of banking sector was also evident. The highest capitalization (PLN $35500 \mathrm{~m}$ ) was achieved by bank PKO BP. The highest percentage of companies which achieved the capitalization higher than PLN $1000 \mathrm{~m}$ was noticed in Banking sector, Telecom sector and in Oil \& Gas sector.

Similarly to the case of capitalization, in the same three sectors, the highest average book value and equity was indentified.

To analyse the correlation between ownership structure and performance of the Polish Stock listed companies Pearson's correlation coefficient was used. It is a common measure of linear dependence between two variables. Results are presented in table 4.

For 289 companies, the number of degrees of freedom is $v=289-2=287$, so the minimal value of coefficient to get the statistically significant correlation is 0.0969 (the number is rather low because of the high number of analysed companies). The statistically significant correlations are marked in the table.

Table 4. Correlation indicators for correlations between ownership structure and company performance

\begin{tabular}{|c|c|c|c|c|c|c|c|c|}
\hline & 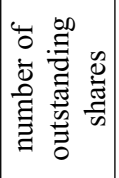 & 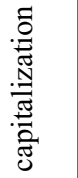 & $\begin{array}{l}\frac{0}{3} \\
\frac{\pi}{2} \\
\frac{\pi}{8} \\
8 \\
0\end{array}$ & $\stackrel{\underline{\Lambda}}{\mathrm{L}}$ & 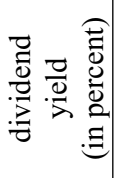 & $\stackrel{m}{m}$ & 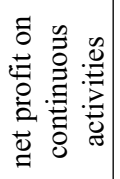 & 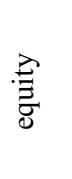 \\
\hline $\begin{array}{l}\text { number of large } \\
\text { shareholders }\end{array}$ & -0.13 & -0.16 & -0.16 & -0.02 & 0.00 & 0.03 & -0.16 & -0.16 \\
\hline $\begin{array}{l}\text { percentage of shares } \\
\text { owned by large } \\
\text { shareholders }\end{array}$ & -0.05 & 0.01 & -0.02 & 0.08 & 0.00 & 0.18 & 0.02 & -0.01 \\
\hline $\begin{array}{l}\text { percentage of voting } \\
\text { rights of the largest } \\
\text { shareholders }\end{array}$ & -0.08 & -0.02 & -0.05 & 0.09 & -0.02 & 0.16 & 0.00 & -0.04 \\
\hline $\begin{array}{l}\text { percentage of voting } \\
\text { rights of the largest } \\
\text { shareholder }\end{array}$ & 0.05 & 0.13 & 0.11 & 0.03 & 0.00 & 0.11 & 0.13 & 0.12 \\
\hline $\begin{array}{l}\text { percentage of voting } \\
\text { rights of the largest } \\
\text { outside shareholders }\end{array}$ & 0.11 & 0.00 & 0.03 & -0.02 & -0.02 & 0.03 & -0.03 & 0.02 \\
\hline $\begin{array}{l}\text { percentage of shares } \\
\text { owned by the members } \\
\text { of management board }\end{array}$ & -0.10 & -0.11 & -0.14 & 0.06 & -0.01 & 0.06 & -0.08 & -0.14 \\
\hline free float & 0.03 & -0.01 & 0.00 & -0.08 & 0.00 & -0.18 & -0.02 & 0.00 \\
\hline $\begin{array}{l}\text { percentage of shares } \\
\text { owned by the outside } \\
\text { shareholders }\end{array}$ & 0.12 & 0.00 & 0.03 & -0.07 & -0.02 & -0.09 & -0.05 & 0.02 \\
\hline
\end{tabular}

Source: own compilation. 
According to the Pearson coefficients (table 4), in companies with higher financial indicators: net profit on continuous activities, equity, book value and capitalization, the number of large shareholders is lower. However, there is a positive correlation only between percentage of shares (or voting rights) owned by large shareholders and $\mathrm{P} / \mathrm{BV}$ indicator. In other words, a higher percentage of shares (or voting rights) owned by large shareholders makes stock investors think that management board is able to create more value from a given set of assets.

Correlations are more obvious in the case of the percentage of the largest shareholder's voting rights. In companies with higher financial indicators, such as net profit on continuous activities, equity, book value, $\mathrm{P} / \mathrm{BV}$ and capitalization, the percentage of voting rights of the one largest shareholder is also higher. The reason why the correlation is not statistically significant for dividend yield can be the fact that the data relate to the crisis period, where only $23.4 \%$ of companies were paying dividend yield.

As a result, it can be stated that the largest shareholder has stronger impact on company performance. The reason can be the fact that the first largest shareholder is very often a mother company for the analysed firm. The larger the mother company, the better effect it will have on the controlled company.

The similar conclusion can be drawn from the analysis of the negative correlation between free float and P/BV. It implies that a higher level of ownership concentration (lower free float) makes investors expect the management to create more value from a given set of assets (higher is $\mathrm{P} / \mathrm{BV}$ ratio).

Both situations: of the higher percentage of voting rights of largest outside shareholders and the one with the lower percentage of shares owned by the members of management board takes place in case of companies with the higher number of outstanding shares. Higher outside shareholders ownership or lower management ownership takes place especially in case of companies listed on the stock market for a long time (subsequent share issues). It just confirms the fact, that if companies put more shares on the market, it decreases the participation of inside shareholders in the company's ownership.

In the light of previous statement, the correlation between the percentage of shares owned by outside shareholders and the number of outstanding shares is rather obvious. While it is quite surprising that the percentage of shares owned by the outside shareholders is not correlated with any financial indicator.

However, it is worth emphasizing that the higher percentage of shares owned by members of management board can be found in companies with the lower economic indicators such as equity, book value and capitalization. In conclusion, that statement is coherent with the Entrenchment Theory.

\section{Conclusion}

While conducting the research, the main difficulty was to establish the connections between the members of management board, companies' owners and the members of supervisory board. Although all the connections should be announced, they were not.

Furthermore, share prices could not be taken into consideration. The reason was that there was a sudden decrease in share prices in the year 2008. Moreover, the share prices tend to fluctuate. Similarly, dividends are not reliable data because only $23.4 \%$ of the analysed companies were paying dividends.

In conclusion, the most important findings are:

- positive correlation between percentage of voting rights of the largest shareholder and performance indicators which indicate the crucial role of the largest shareholder; 
- negative correlation between the management ownership and economic indicators such as equity, book value and capitalization, which confirms the Entrenchment Theory.

According to the Trade-off Theory, the optimal level of insider ownership will vary by company. However, for some sectors the relations are more visible. It can be clearly seen in the case of Banking sector, for which the higher inside ownership and high percentage of ownership in possession of large shareholders is correlated with high performance. For further research it will be necessary to build dynamic model as there are no oblivious correlations between the ownership structure and company performance.

\section{References}

1. Berle A. A., Means G. C., (1932), The Modern Corporation and Private Property, New York, Macmillan.

2. Bøhren Ø., Ødegaard B. A., (2003) Governance and performance revisited, ECGI Finance Working Paper No. 028/2003, http://papers.ssrn.com/sol3/papers.cfm? abstract_id=423461, (as of 10.05.2010).

3. Demsetz H. (1983), The Structure of Ownership and the Theory of the Firm, Journal of Law \& Economics, University of Chicago Press, Vol. 26, No. 2, pp. 375-390.

4. Insider Ownership and REIT Performance - Is More Always Better?, (2001), Prudential Real Estate Investors, Newark, New Jersey.

5. Jensen M. C., Meckling W. H., 1976, Theory of the firm: managerial behavior, agency costs and ownership structure, Journal of Financial Economics, Vol. 3, No. 4, pp. 305-360.

6. O’Sullivan N., Wong P., (1998), Internal versus External Control: An Analysis of Board Composition and Ownership in UK Takeovers Journal of Management and Governance, Vol. 2, No. 1, pp. 17-35.

7. Shleifer A., Vishny R. W., (1986), Large Shareholders and Corporate Control, The Journal of Political Economy, Vol. 94, No. 3, pp. 461-488.

8. Stulz, R., (1988), Managerial control of voting rights: Financing policies and the market for corporate control, Journal of Financial Economics Vol. 20, No. 1, pp. 25-54.

9. Warsaw Stock Exchange's website (www.gpw.pl). 